\title{
REVIEW
}

\section{Alpha-synuclein biology in Lewy body diseases}

\author{
Woojin Scott Kim ${ }^{1,2^{*}}$, Katarina Kågedal ${ }^{3}$ and Glenda M Halliday ${ }^{1,2}$
}

\begin{abstract}
a-Synuclein is an abundantly expressed neuronal protein that is at the center of focus in understanding a group of neurodegenerative disorders called $a$-synucleinopathies, which are characterized by the presence of aggregated a-synuclein intracellularly. Primary a-synucleinopathies include Parkinson's disease (PD), dementia with Lewy bodies and multiple system atrophy, with a-synuclein also found secondarily in a number of other diseases, including Alzheimer's disease. Understanding how a-synuclein aggregates form in these different disorders is important for the understanding of its pathogenesis in Lewy body diseases. PD is the most prevalent of the a-synucleinopathies and much of the initial research on a-synuclein Lewy body pathology was based on PD but is also relevant to Lewy bodies in other diseases (dementia with Lewy bodies and Alzheimer's disease). Polymorphism and mutation studies of SNCA, the gene that encodes a-synuclein, provide much evidence for a causal link between a-synuclein and PD. Among the primary a-synucleinopathies, multiple system atrophy is unique in that a-synuclein deposition occurs in oligodendrocytes rather than neurons. It is unclear whether a-synuclein originates from oligodendrocytes or whether it is transmitted somehow from neurons. a-Synuclein exists as a natively unfolded monomer in the cytosol, but in the presence of lipid membranes it is thought to undergo a conformational change to a folded a-helical secondary structure that is prone to forming dimers and oligomers. Posttranslational modification of a-synuclein, such as phosphorylation, ubiquitination and nitration, has been widely implicated in a-synuclein aggregation process and neurotoxicity. Recent studies using animal and cell models, as well as autopsy studies of patients with neuron transplants, provided compelling evidence for prion-like propagation of a-synuclein. This observation has implications for therapeutic strategies, and much recent effort is focused on developing antibodies that target extracellular a-synuclein.
\end{abstract}

\section{Introduction}

$\alpha$-Synuclein is a 140 amino acid, natively unfolded protein predominantly localized in the presynaptic terminals of neurons. In the past two decades $\alpha$-synuclein has been the center of focus in understanding the etiology of a group of overlapping neurodegenerative disorders called $\alpha$-synucleinopathies, which includes Parkinson's disease (PD), Parkinson's disease dementia (PDD), dementia with Lewy bodies (DLB), multiple system atrophy (MSA) and a number of less-well characterized neuroaxonal dystrophies. $\alpha$-Synuclein is encoded by the SNCA gene on $4 \mathrm{q} 21$, and was first identified as the nonamyloid component of $\beta$-amyloid plaques in the brain of patients with Alzheimer's disease (AD) [1]. Although $\mathrm{AD}$ is pathologically

\footnotetext{
* Correspondence: w.kim@unsw.edu.au

'Neuroscience Research Australia, Barker Street, Randwick, NSW 2031, Australia

${ }^{2}$ School of Medical Sciences, University of New South Wales, Sydney, NSW 2052, Australia

Full list of author information is available at the end of the article
}

quite distinct from $\alpha$-synucleinopathies, $\alpha$-synuclein aggregates have been found in the majority of AD brains, mostly restricted to the amygdala [2,3]. Despite much research into $\alpha$-synuclein biology, the exact function of $\alpha$-synuclein is still elusive. $\alpha$-Synuclein is thought to play a role in maintaining a supply of synaptic vesicles in presynaptic terminals. The protein has also been suggested to be involved in regulating the release of the neurotransmitter dopamine in controlling voluntary and involuntary movements.

The universal feature of $\alpha$-synucleinopathies is the presence of proteinaceous intracellular entities or bodies containing aggregates of $\alpha$-synuclein. These bodies differ somewhat in appearance in different $\alpha$-synucleinopathies, and are called Lewy bodies in PD and DLB [4], glial cytoplasmic inclusions in MSA [5] and axonal spheroids in neuroaxonal dystrophies [6]. Much evidence indicates that the mechanism underpinning $\alpha$-synucleinopathies is the misfolding of $\alpha$-synuclein into aggregates [4]. In vitro 
studies have shown that $\alpha$-synuclein aggregates (that is, oligomers) cause a series of secondary processes leading to neuroinflammation, neurodegeneration and cell death [7]. Apart from the pathogenic dogma of neurotoxicity of aggregated $\alpha$-synuclein, loss of $\alpha$-synuclein monomers (that is, loss of function) from their physiological location may also contribute to neurodegeneration [8]. A radical idea of prion-like propagation has been proposed for $\alpha$-synuclein transmission between cells. New developments in $\alpha$-synuclein transmission highlight the importance of extracellular $\alpha$-synuclein in therapeutic strategies. In this review we will discuss $\alpha$-synuclein biology, $\alpha$ synucleinopathies and recent developments in $\alpha$-synuclein disease mechanisms and therapies.

\section{a-Synuclein biology}

$\alpha$-Synuclein is abundantly expressed in the human brain, making up as much as $1 \%$ of protein content in the cytosol. This protein is expressed throughout the brain, with high levels in the neocortex, hippocampus, substantia nigra, thalamus and cerebellum. It is predominantly expressed in neurons and to a lesser extent in glial cells. Apart from the predominant 140 amino acid protein, there are at least two other alternatively spliced variants of the protein; the 126 amino acid and 112 amino acid variants that lack exon 3 and exon 5, respectively [9]. The $\alpha$-synuclein protein has three distinct structural domains. The amphipathic $\mathrm{N}$-terminal region (residues 1 to 60 ) contains 11 amino acid repeats including the consensus sequence KTKEGV, which is important in $\alpha$-helix formation [10]. The central hydrophobic region (residues 61 to 95) contains the nonamyloid component region, which is important in protein aggregation [4]. Finally, the C-terminal region (residues 96 to 140) is highly acidic and proline rich.

$\alpha$-Synuclein is encoded by the $S N C A$ gene. PD genomewide association studies have shown that single nucleotide polymorphisms in $S N C A$ are strongly associated with an increased risk for idiopathic PD [11-14]. The SNCA missense mutation Ala53Thr was the first causal mutation identified in dominantly inherited PD [15]. Several SNCA missense mutations (for example, Glu46Lys, His50Gln, Gly51Asp and Ala30Pro) have since been identified in dominantly inherited PD [16-19]. In 1998 Conway and colleagues demonstrated that SNCA missense mutations accelerated $\alpha$-synuclein fibril formation in vitro, implicating $\alpha$-synuclein misfolding and aggregation in PD pathogenesis [20]. SNCA duplication and triplication have also been identified in PD subjects [21-25].

Although the exact function of $\alpha$-synuclein is unknown, $\alpha$-synuclein is thought to play a role in maintaining a supply of synaptic vesicles in mature presynaptic terminals, because its expression was detected only after synaptic development [26]. In vitro knockdown studies showed that $\alpha$-synuclein regulates the quantity of different pools of synaptic vesicles in mature neurons [26], influencing synaptic activity as a molecular chaperone in the formation of SNARE complexes [27], a requirement for presynaptic nerve terminal release of neurotransmitters [28]. In this way, $\alpha$-synuclein may regulate the release of dopamine in controlling voluntary and involuntary movements, or might influence memory and cognitive function as shown in SNCA knockout mice [29]. This function of $\alpha$-synuclein becomes more important during increased synaptic activity and aging, and could be a contributory factor in neurodegeneration.

\section{Posttranslational modification of a-synuclein}

Posttranslational modification of $\alpha$-synuclein is prevalent and altered $\alpha$-synuclein proteins impact on a number of pathological processes, including $\alpha$-synuclein aggregation, Lewy body formation and neurotoxicity. The most common posttranslational modification of $\alpha$-synuclein is phosphorylation, which occurs predominantly at serine residues S129 and, to a lesser extent, S87 and at tyrosine residues Y125, Y133 and Y135 [30,31]. In DLB brains, approximately $90 \%$ of insoluble $\alpha$-synuclein is phosphorylated at S129 compared with only $4 \%$ in soluble cytosolic $\alpha$-synuclein [32], implicating phosphorylated $\alpha$-synuclein in the process of $\alpha$-synuclein aggregation.

The second most common posttranslational modification of $\alpha$-synuclein is ubiquitination - the attachment of ubiquitin to $\alpha$-synuclein at lysine residues. Although $\alpha$ synuclein contains 15 lysine residues, $\alpha$-synuclein isolated from Lewy bodies shows that the protein is ubiquitinated mainly at K6, K10 and $\mathrm{K} 12$ residues. Ubiquitination of $\alpha-$ synuclein causes changes in $\alpha$-synuclein function/activity, impacting on $\alpha$-synuclein localization and $\alpha$-synuclein degradation processes [33-35].

Another common posttranslational modification of $\alpha$ synuclein is nitration - the attachment of a nitro molecule to $\alpha$-synuclein at tyrosine residues (Y39, Y125, Y133 and Y136). High concentrations of nitrated $\alpha$-synuclein are found in Lewy bodies [36]. Nitration of $\alpha$-synuclein is enhanced under conditions of elevated oxidative stress, which is widely regarded as an important factor in Lewy body diseases. In vitro studies have shown that nitration of $\alpha$-synuclein induced $\alpha$-synuclein oligomer formation and mitochondrial impairment, leading to apoptosis via the integrin pathway [37]. In a PD cell model, nitration of $\alpha$ synuclein (via increased nitric oxide production) caused increases in the level of neurotoxic $\alpha$-synuclein species and cell death [38].

\section{Prion-like propagation of a-synuclein}

In 2008, two autopsy studies of patients with PD who survived more than 10 years after receiving successful 
transplants of embryonic dopamine neurons to treat their disease observed that the surviving transplanted neurons had $\alpha$-synuclein accumulation in typical Lewy bodies $[39,40]$. The only way these neurons could have such pathology was by a propagating mechanism, a concept of transmission more commonly associated with prion diseases [41]. It should be noted that Braak and colleagues had in 2003 proposed a transmissible mechanism for $\alpha$ synuclein propagation based on observations that the disease seemed to start in the nose and/or gut and progress to invade the brain in a staged manner $[42,43]$. A number of subsequent studies in animal and cell culture models have proven this concept of transmission of $\alpha$-synuclein between neurons, showing that exogenous $\alpha$-synuclein induces Lewy body pathology along neuroanatomical pathways in the brain (for example [44-48]). It should be noted that it is the conformation of the protein that is transmitted to endogenous protein residing within neurons, as in mouse models the aggregates from exogenous sources disappear in about a week with endogenous aggregates beginning around 3 months later [49]. This observation suggests that a particular strain of $\alpha$-synuclein is transmitted between neurons.

Consistent with the concept of different prion strains [50], a number of studies have now identified and characterized different strains of $\alpha$-synuclein. Strains made in vivo exhibit fundamentally different properties, including the packing of their building blocks and growth and amplification properties, as well as their tropism, cellular binding and penetration properties and toxicity $[51,52]$. These differences can be exaggerated by modifying the solution concentration, molecular crowding, agitation, temperature, $\mathrm{pH}$ and ionic strength [53]. Exogenous factors that accelerate the in vitro aggregation of $\alpha$-synuclein include agrochemicals, polycations, histones, metal ions, glycosaminoglycans, sodium dodecyl sulfate and organic solvents, while factors that inhibit $\alpha$-synuclein aggregation include small chemical compounds, heat shock proteins, PAMAM dendrimers, $\beta$ synuclein and $\gamma$-synuclein, catecholamines, phospholipids, rifampicin, trehalose and oxidative modifications [53]. The combination of different factors may impact on the strains of $\alpha$-synuclein in different people and may explain some of the heterogeneity that is known both clinically and pathologically, and especially in the dynamics of the different types of Lewy body diseases [54]. Morphological and structural differences have been noted in patients with Lewy bodies consistent with the concept of different $\alpha$-synuclein strains - Lewy bodies in the brainstem are morphologically different from those in the cortex [55], and conformationally different strains of $\alpha$-synuclein have been identified from cortical tissue samples of patients with PD depending on the presence or absence of Alzheimer pathologies [52].

\section{Binding and interaction of a-synuclein with lipid membranes}

Under normal conditions, $\alpha$-synuclein exists as a randomly structured and natively unfolded protein and remains as a monomer within the cytoplasm. Under pathological conditions, however, $\alpha$-synuclein undergoes structural/conformational changes causing the monomers to aggregate with each other and become insoluble. Much evidence suggests that changes to the $\alpha$-synuclein structure and properties are initiated when the protein binds and interacts with lipid surfaces, such as lipid droplets, phospholipid bilayers or lipid membranes. When $\alpha$-synuclein monomers, isolated from human neurons, were exposed to synthetic lipid membranes, they readily bound to the membrane surface and formed dimers and oligomers [56,57]. Such an interaction is thought to induce a dramatic change in $\alpha$-synuclein structure from its unfolded form to a folded $\alpha$-helical secondary structure [57]. The imperfect repeats of 11 amino acids present in $\alpha$-synuclein, similar to the amphipathic $\alpha$-helical motif common to apolipoproteins and other lipid-binding proteins, appear to play an important role in the lipid membrane binding process [58]. What is significant about such a change is that the $\alpha$-helical form of $\alpha$-synuclein is prone to forming different types of oligomers, the species that are thought to be toxic to cells. The lipid composition of membranes has been shown to affect the binding/interaction of $\alpha$-synuclein to the membrane and subsequent oligomerization [56,59]. $\alpha$-Synuclein is thought to preferentially bind to regions of membranes that are enriched in lipids [60]. These regions are called lipid rafts and are characterized by high concentrations of cholesterol and sphingolipids and altered surface charge that may favor $\alpha$-synuclein binding. The lipid rafts appear to serve as a platform that promotes $\alpha$-synuclein binding and oligomerization.

Contrary to overwhelming evidence that $\alpha$-synuclein exists as an unfolded monomer in the cytosol, Bartels and colleagues reported that endogenous $\alpha$-synuclein exists predominantly as a folded tetramer $(\sim 58 \mathrm{kDa})$ [61]. The explanation provided by the authors for this apparent difference is that most studies claiming the unfolded monomer hypothesis commonly use sample heating and denaturing gels to analyze $\alpha$-synuclein, whereas the authors used nondenaturing conditions. They have also provided evidence by other means - that is, scanning transmission electron microscopy and cell cross-linking - to confirm the prevalence of $\alpha$-synuclein tetramer in neurons and human brain tissues [61]. Bartels and colleagues proposed that since $\alpha$-synuclein tetramers are less likely to form aggregates, the tetramers first undergo destabilization prior to forming aggregates. The authors suggested that stabilizing the physiological tetramers could reduce $\alpha$-synuclein pathogenicity in PD and other $\alpha$-synucleinopathies. 


\section{Dementia with Lewy bodies}

DLB was initially identified as a dementia syndrome with Lewy body pathology [62], which is now incorporated in the Diagnostic and Statistical Manual criteria as a clinical disease entity (neurocognitive disorder with Lewy bodies). Current objective data suggest that the sensitivity of accurate clinical diagnosis is very low, however, with most clinical cases identified actually having AD rather than DLB at autopsy [63-68], and therefore current diagnostic criteria for DLB exclude cases with coexisting AD pathology [62]. Although DLB remains easy to identify pathologically with different cellular pathologies differentiating it from other dementia syndromes, pathological identification using only Lewy body pathology has been shown to be inaccurate due to overlap with patients without dementia symptoms. Current neuropathological criteria state that neurocognitive syndromes with Lewy bodies are most likely when Lewy bodies are prevalent in at least limbic brain regions, but are also often found in association neocortices [69]. A number of studies have shown that a combination of cellular pathologies, which include $\alpha$-synuclein and $\beta$-amyloid deposition as well as dopamine denervation, assist with differentiating this dementia syndrome from others [54]. Approximately 25\% of DLB patients display significant parkinsonian symptoms at the onset of disease, consistent with an early dopamine denervation, whereas 25\% of DLB patients never develop any parkinsonian symptoms and have less significant dopamine loss. DLB is best conceptualized as a dominant dementia syndrome with multiple pathologies that include Lewy bodies and more frequently has multiple pathologies compared with AD [70]. The diversity of clinical phenotypes associated with DLB is likely to reflect the timing and different combinations of these pathologies within different brain regions.

Because of the difficulty in obtaining clinically proven cases with pathological DLB, studies of the underlying molecular changes in the brain are rare. Interesting pathological differences have been noted - the longer the duration of parkinsonism prior to dementia onset, the less severe the cortical $\alpha$-synuclein and $\beta$-amyloid deposition as well as the cortical cholinergic deficit [71]. DLB patients present significant cholinergic deficits [72-74] and a decrease in serum $\alpha$-synuclein [75].

\section{Parkinson's disease and Parkinson's disease dementia}

In contrast to DLB, which is a dominant dementia syndrome, PD is a dominant movement disorder characterized by the presence of two of four cardinal signs (that is, bradykinesia, rigidity, resting tremor, gait instability) that are responsive to levodopa therapy [76]. Current neuropathological criteria require moderate to severe loss of pigmented dopamine neurons in the substantia nigra along with Lewy bodies at least in the brainstem [69]. PDD was defined in 2007 as a dementia syndrome in patients with an initial diagnosis of PD for more than 1 year [77] and, as stated above for DLB, the cognitive symptoms are thought to occur when Lewy bodies are prevalent in at least limbic brain regions, but often also in association neocortices [69]. A smaller proportion of people with PDD have multiple pathologies [78] as observed in most DLB cases (see above).

Changes in the phosphorylation and solubility of $\alpha$-synuclein occur prior to Lewy body formation in PD and PDD [79-81]. In terms of solubility, the amount of soluble $\alpha$-synuclein is not substantially increased and actually decreases slightly over the course of PD [79,82]. The levels of phosphorylation of $\alpha$-synuclein greatly increase prior to Lewy body formation [79-81] and the Lewy body formation correlates with an enhanced lipid association of $\alpha$-synuclein [79]. In a longitudinal study of patients with PD it took an average 13 years for the propagation of Lewy body aggregates to reach limbic brain regions, and 18 years before aggregates occurred in association cortices in $50 \%$ of PD cases [83]. These studies show that the intracellular changes in $\alpha$-synuclein take considerable time to propagate and that posttranslational modifications of $\alpha$-synuclein are substantial prior to its irreversible fibrilization.

\section{Multiple system atrophy}

MSA is a rapidly progressive neurodegenerative disease characterized by the clinical triad of parkinsonism (similar to PD), cerebellar ataxia and autonomic failure. The distribution of pathology classically encompasses three functional systems in the central nervous system - the striatonigral system, the olivopontocerebellar system and the autonomic system - impacting on movement, muscle control, blood pressure, heart rate and bladder function $[84,85]$. Like PD and DLB, the dominant histopathology of MSA is the presence of misfolded and fibrillar $\alpha$-synuclein in the cytoplasm. However, unlike PD and DLB, the principal site for $\alpha$-synuclein deposition is in the oligodendrocytes rather than neurons. Based on current information, the sequence of pathological events in MSA is now recognized as myelin dysregulation first, followed by demyelination and then neurodegeneration and loss of neurons [86-88]; neurodegeneration therefore appears to be a secondary effect in MSA.

No causal mutations or multiplications of the coding sequence of $\alpha$-synuclein have been identified in MSA cases [89-91], although the search is not exhaustive because MSA is a rare disease. Earlier studies, based on small numbers of MSA cases, have reported that genetic variants of SNCA were associated with MSA [92-94]; however, a recent pioneering genome-wide association study of 918 MSA cases and 3,884 controls found no 
risk-conferring loci on the SNCA gene [95]. Posttranslational modification studies of $\alpha$-synuclein in MSA have shown that phosphorylation and ubiquitination are implicated in the deposition of $\alpha$-synuclein [96], although no definitively causative relationships have yet been established. Furthermore, the origin of $\alpha$-synuclein in oligodendrocytes remains stubbornly enigmatic. Although the evidence of significant physiological expression of $\alpha$-synuclein in mature oligodendrocytes is conflicting [97-99], it has been proposed that upregulation of the SNCA gene in these cells could be the cause of $\alpha$ synuclein aggregation. Nevertheless, successful animal models of MSA, which recapitulate both neuropathological and clinical features, have been generated by overexpression of $\alpha$-synuclein in the oligodendrocytes $[96,100,101]$. Alternatively, aberrant uptake of $\alpha$-synuclein from the extracellular environment has also been proposed as a possible mechanism of $\alpha$-synuclein aggregation in oligodendrocytes $[97,102,103]$.

\section{Lewy body pathology in Alzheimer's disease}

Although Lewy bodies are the pathological hallmark of PD and DLB, recent studies suggest a considerable proportion of $\mathrm{AD}$ brains show $\alpha$-synuclein pathology. In a recent study of 22 clinically diagnosed cases of $\mathrm{AD}, 10$ were found to have $\alpha$-synuclein immunoreactive Lewy bodies by subsequent pathological examination [104]. Other studies showed that as many as one-half of patients with $\mathrm{AD}$, including both sporadic and familial cases, have $\alpha$-synuclein aggregates [2,105-107]. In these studies, $\alpha$-synuclein aggregates were mostly restricted to the amygdala, implying that the spread of $\alpha$-synuclein inclusions is different to that of PD. Lewy pathology in $\mathrm{AD}$ has also been reported to be formed mainly in the cell body of neurons, and not in the axonal terminals and dendrites as in PD $[107,108]$. The Lewy pathology therefore possibly mirrors a nonspecific end stage of AD. However, genetic or lifestyle factors might prime neurons to accumulate $\alpha$-synuclein aggregates in a subset of $\mathrm{AD}$ patients, and thus $\alpha$-synuclein aggregates might reflect a causal pathogenic mechanism in AD.

Several studies show that high levels of AD pathology are often observed in patients with PD and DLB [78] and correlate with the decline in cognitive function more than the amount of $\alpha$-synuclein aggregates [109-111]. Interestingly, $\mathrm{PD} / \mathrm{DLB}$ cases with $\mathrm{AD}$ pathology have higher $\alpha$-synuclein levels in cortical and limbic areas than cases without AD pathology [112], which implies a possible interaction between $\alpha$-synuclein and $\mathrm{AD}$ pathology in these disorders. How the pathologies of $\alpha$-synuclein, $\beta$-amyloid and tau relate to each other in $\mathrm{PD}$ and $\mathrm{AD}$ is poorly understood. Recent work using a transgenic mouse model of DLB-AD provides some clues to the interaction between $\beta$-amyloid, tau and $\alpha$-synuclein [113]. This mouse model was generated from a cross between $3 \times \mathrm{Tg}$-AD mice and mice that express the A53T mutation in $\alpha$-synuclein [114]. The DLB-AD mice exhibited accelerated cognitive decline, compared with $3 \times \mathrm{Tg}$ - $\mathrm{AD}$ mice alone, with more severe $\beta$-amyloid, tau and $\alpha$-synuclein pathologies [113]. These data suggest that the three pathologies interact and somehow enhance each other, resulting in accelerated cognitive dysfunction.

\section{Therapeutic strategies}

Because of the marked cholinergic deficit associated with DLB (see above), cholinesterase inhibitors are routinely used for clinical improvement [115]. In PDD these agents have been shown to improve cognitive function, behavioral disturbances and activities of daily living [115]. Their effect in DLB is less clear [115], potentially because DLB is poorly diagnosed clinically and often has multiple underlying pathologies (see above). Interestingly, successful treatment with cholinesterase inhibitors was shown to decrease $\beta$-amyloid deposition in a small study of DLB patients [116], suggesting that these drugs have mechanistic as well as symptomatic effects. Considering the molecular events surrounding $\alpha$-synuclein deposition, a number of strategies are being developed $[117,118]$. These strategies include small anti-aggregating molecules and chaperones [119-123], but perhaps the most promising strategy is the development of antibody therapies for $\alpha$-synuclein. These therapies target extracellular $\alpha$-synuclein binding the protein to reduce its self-aggregation and increase its clearance, with a number of antibodies already in production [124-127]. Another promising development is the use of the $\beta$-lactum antibiotic ceftriaxone as a therapeutic agent to block $\alpha$-synuclein aggregation [128], although the macrocyclic antibiotic rifampicin has not been successful in MSA [129].

\section{Conclusions}

The assessment of different $\alpha$-synucleinopathies focuses on a variety of mechanisms that affect the pathogenesis of Lewy body diseases. While all $\alpha$-synucleinopathies are characterized by $\alpha$-synuclein aggregates with similar posttranslational modifications and lipid associations, the cell type involved, their location and their association with other protein depositions vary substantially, and recent data suggest that perhaps the strain of $\alpha$-synuclein involved may also differ. An increase in $\alpha$-synuclein is hypothesized to precipitate the protein's aggregation, and this is evident in some familial forms of PD, but the precipitating events for most of the $\alpha$-synucleinopathies remain to be determined. It is clear for Lewy body disorders that the neuronal propagation can be slow or rapid, and is impacted on by AD pathology; however, Lewy bodies in $\mathrm{AD}$ are focused in the amygdala, suggesting that the 
initiating region of $\alpha$-synuclein aggregation in the brain can be diverse. Importantly, the concept of propagation of $\alpha$-synuclein pathology between neurons has resulted in the development of new therapies that target this mechanism with the potential to halt or slow this aspect of Lewy body diseases.

Note: This article is part of a series on Lewy Body Dementia, edited by lan McKeith and James Galvin. Other articles in this series can be found at http://alzres.com/series/LewyBodyDementia.

\section{Abbreviations}

AD: Alzheimer's disease; DLB: Dementia with Lewy bodies; MSA: Multiple system atrophy; PD: Parkinson's disease; PDD: Parkinson's disease dementia.

\section{Competing interests}

The authors declare that they have no competing interests.

\section{Acknowledgements}

This work was supported by a National Health and Medical Research Council of Australia (NHMRC) project grant (\#1022325). GMH is a NHMRC Senior Principal Research Fellow (\#630434).

\section{Author details}

${ }^{1}$ Neuroscience Research Australia, Barker Street, Randwick, NSW 2031, Australia. ${ }^{2}$ School of Medical Sciences, University of New South Wales, Sydney, NSW 2052, Australia. ${ }^{3}$ Department of Clinical and Experimental Medicine, Linköping University, SE-581 85 Linköping, Sweden.

\section{Published online: 27 October 2014}

\section{References}

1. Ueda K, Fukushima H, Masliah E, Xia Y, Iwai A, Yoshimoto M, Otero DA, Kondo J, Ihara Y, Saitoh T: Molecular cloning of CDNA encoding an unrecognized component of amyloid in Alzheimer disease. Proc Natl Acad Sci U S A 1993, 90:11282-11286.

2. Lippa CF, Fujiwara H, Mann DM, Giasson B, Baba M, Schmidt ML, Nee LE, O'Connell B, Pollen DA, St George-Hyslop P, Ghetti B, Nochlin D, Bird TD, Cairns NJ, Lee VM, Iwatsubo T, Trojanowski JQ: Lewy bodies contain altered alpha-synuclein in brains of many familial Alzheimer's disease patients with mutations in presenilin and amyloid precursor protein genes. Am J Pathol 1998, 153:1365-1370.

3. Arai Y, Yamazaki M, Mori O, Muramatsu H, Asano G, Katayama Y: Alphasynuclein-positive structures in cases with sporadic Alzheimer's disease: morphology and its relationship to tau aggregation. Brain Res 2001, 888:287-296.

4. Spillantini MG, Schmidt ML, Lee VM, Trojanowski JQ, Jakes R, Goedert M: Alpha-synuclein in Lewy bodies. Nature 1997, 388:839-840.

5. Gai WP, Power JH, Blumbergs PC, Blessing WW: Multiple-system atrophy: a new alpha-synuclein disease? Lancet 1998, 352:547-548.

6. Newell KL, Boyer P, Gomez-Tortosa E, Hobbs W, Hedley-Whyte ET, Vonsattel JP, Hyman BT: Alpha-synuclein immunoreactivity is present in axonal swellings in neuroaxonal dystrophy and acute traumatic brain injury. J Neuropathol Exp Neurol 1999, 58:1263-1268.

7. Wolozin B, Behl C: Mechanisms of neurodegenerative disorders: part 1: protein aggregates. Arch Neurol 2000, 57:793-796.

8. Lashuel HA, Overk CR, Oueslati A, Masliah E: The many faces of alphasynuclein: from structure and toxicity to therapeutic target. Nat Rev Neurosci 2013, 14:38-48.

9. Beyer K: Alpha-synuclein structure, posttranslational modification and alternative splicing as aggregation enhancers. Acta Neuropathol 2006, 112:237-251.

10. Clayton DF, George JM: The synucleins: a family of proteins involved in synaptic function, plasticity, neurodegeneration and disease. Trends Neurosci 1998, 21:249-254.
11. Pals P, Lincoln S, Manning J, Heckman M, Skipper L, Hulihan M, Van den Broeck M, De Pooter T, Cras P, Crook J, Van Broeckhoven C, Farrer MJ: alpha-Synuclein promoter confers susceptibility to Parkinson's disease. Ann Neurol 2004, 56:591-595.

12. Rajput A, Vilarino-Guell C, Rajput ML, Ross OA, Soto-Ortolaza Al, Lincoln SJ, Cobb SA, Heckman MG, Farrer MJ: Alpha-synuclein polymorphisms are associated with Parkinson's disease in a Saskatchewan population. Mov Disord 2009, 24:2411-2414.

13. Pankratz N, Wilk JB, Latourelle JC, DeStefano AL, Halter C, Pugh EW, Doheny KF, Gusella JF, Nichols WC, Foroud T, Myers RH: Genome-wide association study for susceptibility genes contributing to familial Parkinson disease. Hum Genet 2009, 124:593-605.

14. Maraganore DM, de Andrade M, Elbaz A, Farrer MJ, loannidis JP, Kruger R, Rocca WA, Schneider NK, Lesnick TG, Lincoln SJ, Hulihan MM, Aasly JO, Ashizawa T, Chartier-Harlin MC, Checkoway H, Ferrarese C, Hadjigeorgiou G, Hattori N, Kawakami H, Lambert JC, Lynch T, Mellick GD, Papapetropoulos S, Parsian A, Quattrone A, Riess O, Tan EK, Van Broeckhoven C: Collaborative analysis of alpha-synuclein gene promoter variability and Parkinson disease. JAMA 2006, 296:661-670.

15. Polymeropoulos MH, Lavedan C, Leroy E, Ide SE, Dehejia A, Dutra A, Pike B, Root H, Rubenstein J, Boyer R, Stenroos ES, Chandrasekharappa S, Athanassiadou A, Papapetropoulos T, Johnson WG, Lazzarini AM, Duvoisin RC, Di lorio G, Golbe LI, Nussbaum RL: Mutation in the alpha-synuclein gene identified in families with Parkinson's disease. Science 1997, 276:2045-2047.

16. Kruger R, Kuhn W, Muller T, Woitalla D, Graeber M, Kosel S, Przuntek H, Epplen JT, Schols L, Riess O: Ala30Pro mutation in the gene encoding alpha-synuclein in Parkinson's disease. Nat Genet 1998, 18:106-108.

17. Zarranz JJ, Alegre J, Gomez-Esteban JC, Lezcano E, Ros R, Ampuero I, Vidal L, Hoenicka J, Rodriguez O, Atares B, Llorens V, Gomez Tortosa E, del Ser T, Munoz DG, de Yebenes JG: The new mutation, E46K, of alpha-synuclein causes Parkinson and Lewy body dementia. Ann Neurol 2004, 55:164-173.

18. Proukakis C, Dudzik CG, Brier T, MacKay DS, Cooper JM, Millhauser GL, Houlden H, Schapira AH: A novel alpha-synuclein missense mutation in Parkinson disease. Neurology 2013, 80:1062-1064.

19. Lesage S, Anheim M, Letournel F, Bousset L, Honore A, Rozas N, Pieri L, Madiona K, Durr A, Melki R, Verny C, Brice A: G51D alpha-synuclein mutation causes a novel Parkinsonian-pyramidal syndrome. Ann Neurol 2013, 73:459-471.

20. Conway KA, Harper JD, Lansbury PT: Accelerated in vitro fibril formation by a mutant alpha-synuclein linked to early-onset Parkinson disease. Nat Med 1998, 4:1318-1320.

21. Singleton $A B$, Farrer $M$, Johnson J, Singleton $A$, Hague S, Kachergus J, Hulihan M, Peuralinna T, Dutra A, Nussbaum R, Lincoln S, Crawley A, Hanson M, Maraganore D, Adler C, Cookson MR, Muenter M, Baptista M, Miller D, Blancato J, Hardy J, Gwinn-Hardy K: alpha-Synuclein locus triplication causes Parkinson's disease. Science 2003, 302:841.

22. Chartier-Harlin MC, Kachergus J, Roumier C, Mouroux V, Douay X, Lincoln S, Levecque C, Larvor L, Andrieux J, Hulihan M, Waucquier N, Defebvre L, Amouyel P, Farrer M, Destee A: Alpha-synuclein locus duplication as a cause of familial Parkinson's disease. Lancet 2004, 364:1167-1169.

23. Ibanez P, Bonnet AM, Debarges B, Lohmann E, Tison F, Pollak P, Agid Y, Durr A, Brice A: Causal relation between alpha-synuclein gene duplication and familial Parkinson's disease. Lancet 2004, 364:1169-1171.

24. Fuchs J, Nilsson C, Kachergus J, Munz M, Larsson EM, Schule B, Langston JW, Middleton FA, Ross OA, Hulihan M, Gasser T, Farrer MJ: Phenotypic variation in a large Swedish pedigree due to SNCA duplication and triplication. Neurology 2007, 68:916-922.

25. Nishioka K, Ross OA, Ishii K, Kachergus JM, Ishiwata K, Kitagawa M, Kono S, Obi T, Mizoguchi K, Inoue Y, Imai H, Takanashi M, Mizuno Y, Farrer MJ, Hattori N: Expanding the clinical phenotype of SNCA duplication carriers. Mov Disord 2009, 24:1811-1819.

26. Murphy DD, Rueter SM, Trojanowski JQ, Lee VM: Synucleins are developmentally expressed, and alpha-synuclein regulates the size of the presynaptic vesicular pool in primary hippocampal neurons. J Neurosci 2000, 20:3214-3220.

27. Bonini NM, Giasson Bl: Snaring the function of alpha-synuclein. Cell 2005, 123:359-361.

28. Burre J, Sharma M, Tsetsenis T, Buchman V, Etherton MR, Sudhof TC: Alpha-synuclein promotes SNARE-complex assembly in vivo and in vitro. Science 2010, 329:1663-1667. 
29. Kokhan VS, Afanasyeva MA, Van'kin Gl: alpha-Synuclein knockout mice have cognitive impairments. Behav Brain Res 2012, 231:226-230.

30. Okochi M, Walter J, Koyama A, Nakajo S, Baba M, Iwatsubo T, Meijer L, Kahle PJ, Haass C: Constitutive phosphorylation of the Parkinson's disease associated alpha-synuclein. J Biol Chem 2000, 275:390-397.

31. Nakamura T, Yamashita H, Takahashi T, Nakamura S: Activated Fyn phosphorylates alpha-synuclein at tyrosine residue 125. Biochem Biophys Res Commun 2001, 280:1085-1092.

32. Anderson JP, Walker DE, Goldstein JM, de Laat R, Banducci $K$, Caccavello RJ, Barbour R, Huang J, Kling K, Lee M, Diep L, Keim PS, Shen X, Chataway T, Schlossmacher MG, Seubert P, Schenk D, Sinha S, Gai WP, Chilcote TJ: Phosphorylation of Ser-129 is the dominant pathological modification of alpha-synuclein in familial and sporadic Lewy body disease. $J$ Biol Chem 2006, 281:29739-29752.

33. Nonaka T, Iwatsubo T, Hasegawa M: Ubiquitination of alpha-synuclein. Biochemistry 2005, 44:361-368.

34. House CM, Hancock NC, Moller A, Cromer BA, Fedorov V, Bowtell DD, Parker MW, Polekhina G: Elucidation of the substrate binding site of Siah ubiquitin ligase. Structure 2006, 14:695-701.

35. Lee JT, Wheeler TC, Li L, Chin LS: Ubiquitination of alpha-synuclein by Siah-1 promotes alpha-synuclein aggregation and apoptotic cell death. Hum Mol Genet 2008, 17:906-917.

36. Giasson BI, Duda JE, Murray IV, Chen Q, Souza JM, Hurtig HI, Ischiropoulos H, Trojanowski JQ, Lee VM: Oxidative damage linked to neurodegeneration by selective alpha-synuclein nitration in synucleinopathy lesions. Science 2000, 290:985-989.

37. Liu $Y$, Qiang $M$, Wei $Y$, He R: A novel molecular mechanism for nitrated a-synuclein-induced cell death. J Mol Cell Biol 2011, 3:239-249.

38. Danielson SR, Held JM, Schilling B, Oo M, Gibson BW, Andersen JK: Preferentially increased nitration of alpha-synuclein at tyrosine-39 in a cellular oxidative model of Parkinson's disease. Anal Chem 2009, 81:7823-7828.

39. Kordower JH, Chu Y, Hauser RA, Freeman TB, Olanow CW: Lewy body-like pathology in long-term embryonic nigral transplants in Parkinson's disease. Nat Med 2008, 14:504-506.

40. Li JY, Englund E, Holton JL, Soulet D, Hagell P, Lees AJ, Lashley T, Quinn NP, Rehncrona S, Bjorklund A, Widner H, Revesz T, Lindvall O, Brundin P: Lewy bodies in grafted neurons in subjects with Parkinson's disease suggest host-to-graft disease propagation. Nat Med 2008, 14:501-503.

41. Brundin P, Melki R, Kopito R: Prion-like transmission of protein aggregates in neurodegenerative diseases. Nat Rev Mol Cell Biol 2010, 11:301-307.

42. Braak H, Del Tredici K, Rub U, de Vos RA, Jansen Steur EN, Braak E: Staging of brain pathology related to sporadic Parkinson's disease. Neurobiol Aging 2003, 24:197-211.

43. Braak H, Rub U, Gai WP, Del Tredici K: Idiopathic Parkinson's disease: possible routes by which vulnerable neuronal types may be subject to neuroinvasion by an unknown pathogen. J Neural Transm 2003, 110:517-536.

44. Hansen $C$, Angot $E$, Bergstrom AL, Steiner JA, Pieri L, Paul G, Outeiro TF, Melki R, Kallunki P, Fog K, Li JY, Brundin P: alpha-Synuclein propagates from mouse brain to grafted dopaminergic neurons and seeds aggregation in cultured human cells. J Clin Invest 2011, 121:715-725.

45. Ulusoy A, Rusconi R, Perez-Revuelta Bl, Musgrove RE, Helwig M, Winzen-Reichert B, Di Monte DA: Caudo-rostral brain spreading of alpha-synuclein through vagal connections. EMBO Mol Med 2013, 5:1051-1059.

46. Rey NL, Petit GH, Bousset $L$, Melki R, Brundin P: Transfer of human alphasynuclein from the olfactory bulb to interconnected brain regions in mice. Acta Neuropathol 2013, 126:555-573.

47. Luk KC, Lee VM: Modeling Lewy pathology propagation in Parkinson's disease. Parkinsonism Relat Disord 2014, 20:S85-S87.

48. Recasens A, Dehay B, Bove J, Carballo-Carbajal I, Dovero S, Perez-Villalba A Fernagut PO, Blesa J, Parent A, Perier C, Farinas I, Obeso JA, Bezard E, Vila M: Lewy body extracts from Parkinson disease brains trigger alphasynuclein pathology and neurodegeneration in mice and monkeys. Ann Neurol 2014, 75:351-362.

49. Masuda-Suzukake M, Nonaka T, Hosokawa M, Oikawa T, Arai T, Akiyama H, Mann DM, Hasegawa M: Prion-like spreading of pathological alphasynuclein in brain. Brain 2013, 136:1128-1138.

50. Kretzschmar $\mathrm{H}$, Tatzelt J: Prion disease: a tale of folds and strains. Brain Pathol 2013, 23:321-332.
51. Bousset L, Pieri L, Ruiz-Arlandis G, Gath J, Jensen PH, Habenstein B, Madiona K, Olieric V, Bockmann A, Meier BH, Melki R: Structural and functional characterization of two alpha-synuclein strains. Nat Commun 2013, 4:2575.

52. Guo JL, Covell DJ, Daniels JP, Iba M, Stieber A, Zhang B, Riddle DM, Kwong LK, Xu Y, Trojanowski JQ, Lee VM: Distinct alpha-synuclein strains differentially promote tau inclusions in neurons. Cell 2013, 154:103-117.

53. Narkiewicz J, Giachin G, Legname G: In vitro aggregation assays for the characterization of alpha-synuclein prion-like properties. Prion 2014, 8:19-32.

54. Halliday GM, Holton JL, Revesz T, Dickson DW: Neuropathology underlying clinical variability in patients with synucleinopathies. Acta Neuropathol 2011, 122:187-204.

55. Spillantini MG, Crowther RA, Jakes R, Hasegawa M, Goedert M: alphaSynuclein in filamentous inclusions of Lewy bodies from Parkinson's disease and dementia with lewy bodies. Proc Natl Acad Sci U S A 1998, 95:6469-6473.

56. Leng Y, Chase TN, Bennett MC: Muscarinic receptor stimulation induces translocation of an alpha-synuclein oligomer from plasma membrane to a light vesicle fraction in cytoplasm. J Biol Chem 2001, 276:28212-28218.

57. Davidson WS, Jonas A, Clayton DF, George JM: Stabilization of alphasynuclein secondary structure upon binding to synthetic membranes. J Biol Chem 1998, 273:9443-9449.

58. Segrest JP, Jones MK, De Loof H, Brouillette CG, Venkatachalapathi $Y$, Anantharamaiah GM: The amphipathic helix in the exchangeable apolipoproteins: a review of secondary structure and function. J Lipid Res 1992, 33:141-166.

59. Cole NB, Murphy DD, Grider T, Rueter S, Brasaemle D, Nussbaum RL: Lipid droplet binding and oligomerization properties of the Parkinson's disease protein alpha-synuclein. J Biol Chem 2002, 277:6344-6352.

60. Fortin DL, Troyer MD, Nakamura K, Kubo S, Anthony MD, Edwards RH: Lipid rafts mediate the synaptic localization of alpha-synuclein. J Neurosci 2004, 24:6715-6723

61. Bartels T, Choi JG, Selkoe DJ: alpha-Synuclein occurs physiologically as a helically folded tetramer that resists aggregation. Nature 2011, 477:107-110.

62. McKeith IG, Dickson DW, Lowe J, Emre M, O'Brien JT, Feldman H, Cummings J, Duda JE, Lippa C, Perry EK, Aarsland D, Arai H, Ballard CG, Boeve B, Burn DJ, Costa D, Del Ser T, Dubois B, Galasko D, Gauthier S, Goetz CG, Gomez-Tortosa E, Halliday G, Hansen LA, Hardy J, Iwatsubo T, Kalaria RN, Kaufer D, Kenny RA, Korczyn A, et al: Diagnosis and management of dementia with Lewy bodies: third report of the DLB Consortium. Neurology 2005, 65:1863-1872.

63. Weisman D, Cho M, Taylor C, Adame A, Thal LJ, Hansen LA: In dementia with Lewy bodies, Braak stage determines phenotype, not Lewy body distribution. Neurology 2007, 69:356-359.

64. Fujishiro H, Ferman TJ, Boeve BF, Smith GE, Graff-Radford NR, Uitti RJ, Wszolek ZK, Knopman DS, Petersen RC, Parisi JE, Dickson DW: Validation of the neuropathologic criteria of the third consortium for dementia with Lewy bodies for prospectively diagnosed cases. I Neuropathol Exp Neurol 2008, 67:649-656.

65. Oinas M, Polvikoski T, Sulkava R, Myllykangas L, Juva K, Notkola IL, Rastas S, Niinisto L, Kalimo H, Paetau A: Neuropathologic findings of dementia with lewy bodies (DLB) in a population-based Vantaa 85+ study. J Alzheimers Dis 2009, 18:677-689.

66. Walker Z, Jaros E, Walker RW, Lee L, Costa DC, Livingston G, Ince PG, Perry R, McKeith I, Katona CL: Dementia with Lewy bodies: a comparison of clinical diagnosis, FP-CIT single photon emission computed tomography imaging and autopsy. J Neurol Neurosurg Psychiatry 2007, 78:1176-1181.

67. Nelson PT, Jicha GA, Kryscio RJ, Abner EL, Schmitt FA, Cooper G, Xu LO, Smith CD, Markesbery WR: Low sensitivity in clinical diagnoses of dementia with Lewy bodies. J Neurol 2010, 257:359-366.

68. Ferman TJ, Boeve BF, Smith GE, Lin SC, Silber MH, Pedraza O, Wszolek Z, Graff-Radford NR, Uitti R, Van Gerpen J, Pao W, Knopman D, Pankratz VS, Kantarci K, Boot B, Parisi JE, Dugger BN, Fujishiro H, Petersen RC, Dickson DW: Inclusion of RBD improves the diagnostic classification of dementia with Lewy bodies. Neurology 2011, 77:875-882.

69. Dickson DW, Braak H, Duda JE, Duyckaerts C, Gasser T, Halliday GM, Hardy J, Leverenz JB, Del Tredici K, Wszolek ZK, Litvan I: Neuropathological assessment of Parkinson's disease: refining the diagnostic criteria. Lancet Neurol 2009, 8:1150-1157. 
70. Kovacs GG, Alafuzoff I, Al-Sarraj S, Arzberger T, Bogdanovic N, Capellari S, Ferrer I, Gelpi E, Kovari V, Kretzschmar H, Nagy Z, Parchi P, Seilhean D, Soininen $H$, Troakes $C$, Budka H: Mixed brain pathologies in dementia: the BrainNet Europe consortium experience. Dement Geriatr Cogn Disord 2008, 26:343-350.

71. Ballard C, Ziabreva I, Perry R, Larsen JP, O'Brien J, McKeith I, Perry E, Aarsland $D$ : Differences in neuropathologic characteristics across the Lewy body dementia spectrum. Neurology 2006, 67:1931-1934.

72. Tiraboschi P, Hansen LA, Alford M, Sabbagh MN, Schoos B, Masliah E, Thal $\sqcup$, Corey-Bloom J: Cholinergic dysfunction in diseases with Lewy bodies. Neurology 2000, 54:407-411.

73. Shimada H, Hirano S, Shinotoh H, Aotsuka A, Sato K, Tanaka N, Ota T, Asahina M, Fukushi K, Kuwabara S, Hattori T, Suhara T, Irie T: Mapping of brain acetylcholinesterase alterations in Lewy body disease by PET. Neurology 2009, 73:273-278.

74. Marcone A, Garibotto V, Moresco RM, Florea I, Panzacchi A, Carpinelli A, Virta JR, Tettamanti M, Borroni B, Padovani A, Bertoldo A, Herholz K, Rinne JO, Cappa SF, Perani D: [11C]-MP4A PET cholinergic measurements in amnestic mild cognitive impairment, probable Alzheimer's disease, and dementia with Lewy bodies: a Bayesian method and voxel-based analysis. J Alzheimers Dis 2012, 31:387-399.

75. Laske C, Fallgatter AJ, Stransky E, Hagen K, Berg D, Maetzler W: Decreased alpha-synuclein serum levels in patients with Lewy body dementia compared to Alzheimer's disease patients and control subjects. Dement Geriatr Cogn Disord 2011, 31:413-416.

76. Gelb DJ, Oliver E, Gilman S: Diagnostic criteria for Parkinson disease. Arch Neurol 1999, 56:33-39.

77. Emre M, Aarsland D, Brown R, Burn DJ, Duyckaerts C, Mizuno Y, Broe GA, Cummings J, Dickson DW, Gauthier S, Goldman J, Goetz C, Korczyn A, Lees A, Levy R, Litvan I, McKeith I, Olanow W, Poewe W, Quinn N, Sampaio C, Tolosa E, Dubois B: Clinical diagnostic criteria for dementia associated with Parkinson's disease. Mov Disord 2007. 22:1689-1707.

78. Irwin DJ, Lee VM, Trojanowski JQ: Parkinson's disease dementia: convergence of alpha-synuclein, tau and amyloid-beta pathologies. Nat Rev Neurosci 2013, 14:626-636.

79. Zhou J, Broe M, Huang Y, Anderson JP, Gai WP, Milward EA, Porritt M, Howells D, Hughes AJ, Wang X, Halliday GM: Changes in the solubility and phosphorylation of alpha-synuclein over the course of Parkinson's disease. Acta Neuropathol 2011, 121:695-704.

80. Lue LF, Walker DG, Adler CH, Shill H, Tran H, Akiyama H, Sue LI, Caviness J, Sabbagh MN, Beach TG: Biochemical increase in phosphorylated alphasynuclein precedes histopathology of Lewy-type synucleinopathies. Brain Pathol 2012, 22:745-756.

81. Walker DG, Lue LF, Adler CH, Shill HA, Caviness JN, Sabbagh MN, Akiyama $H$, Serrano GE, Sue LI, Beach TG, Arizona Parkinson Disease Consortium: Changes in properties of serine 129 phosphorylated alpha-synuclein with progression of Lewy-type histopathology in human brains. Exp Neurol 2013, 240:190-204.

82. Tong J, Wong H, Guttman M, Ang LC, Forno LS, Shimadzu M, Rajput AH, Muenter MD, Kish SJ, Hornykiewicz O, Furukawa Y: Brain alpha-synuclein accumulation in multiple system atrophy, Parkinson's disease and progressive supranuclear palsy: a comparative investigation. Brain 2010, 133:172-188

83. Halliday $G$, Hely M, Reid W, Morris J: The progression of pathology in longitudinally followed patients with Parkinson's disease. Acta Neuropathol 2008, 115:409-415.

84. Wenning G, Tison F, Ben Shlomo Y, Daniel S, Quinn N: Multiple system atrophy: a review of 203 pathologically proven cases. Mov Disord 1997, 12:133-147.

85. Ozawa T, Okuizumi K, Ikeuchi T, Wakabayashi K, Takahashi H, Tsuji S: Analysis of the expression level of alpha-synuclein mRNA using postmortem brain samples from pathologically confirmed cases of multiple system atrophy. Acta Neuropathol 2001, 102:188-190.

86. Baker KG, Huang Y, McCann H, Gai WP, Jensen PH, Halliday GM: P25alpha immunoreactive but alpha-synuclein immunonegative neuronal inclusions in multiple system atrophy. Acta Neuropathol 2006, 111:193-195.

87. Huang Y, Song YJ, Murphy K, Holton JL, Lashley T, Revesz T, Gai WP Halliday GM: LRRK2 and parkin immunoreactivity in multiple system atrophy inclusions. Acta Neuropathol 2008, 116:639-646.
88. Song $Y$ J, Lundvig DM, Huang Y, Gai WP, Blumbergs PC, Hojrup P, Otzen D, Halliday GM, Jensen PH: p25alpha relocalizes in oligodendroglia from myelin to cytoplasmic inclusions in multiple system atrophy. Am J Pathol 2007, 171:1291-1303.

89. Jin H, Ishikawa K, Tsunemi T, Ishiguro T, Amino T, Mizusawa H: Analyses of copy number and mRNA expression level of the alpha-synuclein gene in multiple system atrophy. J Med Dental Sci 2008, 55:145-153.

90. Morris HR, Vaughan JR, Datta SR, Bandopadhyay R, Rohan De Silva HA, Schrag A, Cairns NJ, Burn D, Nath U, Lantos PL, Daniel S, Lees AJ, Quinn NP, Wood NW: Multiple system atrophy/progressive supranuclear palsy: alpha-synuclein, synphilin, tau, and APOE. Neurology 2000, 55:1918-1920.

91. Ozawa T, Takano H, Onodera O, Kobayashi H, Ikeuchi T, Koide R, Okuizumi K Shimohata T, Wakabayashi K, Takahashi H, Tsuji S: No mutation in the entire coding region of the alpha-synuclein gene in pathologically confirmed cases of multiple system atrophy. Neurosci Lett 1999, 270:110-112.

92. Al-Chalabi A, Durr A, Wood NW, Parkinson MH, Camuzat A, Hulot JS, Morrison KE, Renton A, Sussmuth SD, Landwehrmeyer BG, Ludolph A, Agid Y, Brice A, Leigh PN, Bensimon G: Genetic variants of the alpha-synuclein gene SNCA are associated with multiple system atrophy. PLoS One 2009, 4:e7114.

93. Scholz SW, Houlden H, Schulte C, Sharma M, Li A, Berg D, Melchers A, Paudel R, Gibbs JR, Simon-Sanchez J, Paisan-Ruiz C, Bras J, Ding J, Chen H, Traynor BJ, Arepalli S, Zonozi RR, Revesz T, Holton J, Wood N, Lees A, Oertel W, Wullner U, Goldwurm S, Pellecchia MT, Illig T, Riess O, Fernandez HH, Rodriguez RL, Okun M, et al: SNCA variants are associated with increased risk for multiple system atrophy. Ann Neurol 2009, 65:610-614.

94. Stemberger S, Scholz SW, Singleton AB, Wenning GK: Genetic players in multiple system atrophy: unfolding the nature of the beast. Neurobio Aging 1924, 2011:e5-e14

95. Sailer A, MSA GWAS Consortium: First genome-wide association study in multiple system atrophy. Mov Disord 2012, 27:1425.

96. Stefanova N, Reindl M, Neumann M, Haass C, Poewe W, Kahle PJ, Wenning GK: Oxidative stress in transgenic mice with oligodendroglial alphasynuclein overexpression replicates the characteristic neuropathology of multiple system atrophy. Am J Pathol 2005, 166:869-876.

97. Miller DW, Johnson JM, Solano SM, Hollingsworth ZR, Standaert DG, Young $A B$ : Absence of alpha-synuclein mRNA expression in normal and multiple system atrophy oligodendroglia. J Neural Transm 2005, 112:1613-1624.

98. Mori F, Tanji K, Yoshimoto M, Takahashi H, Wakabayashi K: Demonstration of alpha-synuclein immunoreactivity in neuronal and glial cytoplasm in normal human brain tissue using proteinase $\mathrm{K}$ and formic acid pretreatment. Exp Neurol 2002, 176:98-104.

99. Richter-Landsberg C, Gorath M, Trojanowski JQ, Lee VM: alpha-synuclein is developmentally expressed in cultured rat brain oligodendrocytes. J Neurosci Res 2000, 62:9-14.

100. Kahle PJ, Neumann M, Ozmen L, Muller V, Jacobsen H, Spooren W, Fuss B, Mallon B, Macklin WB, Fujiwara H, Hasegawa M, Iwatsubo T, Kretzschmar HA, Haass C: Hyperphosphorylation and insolubility of alpha-synuclein in transgenic mouse oligodendrocytes. EMBO Rep 2002, 3:583-588.

101. Yazawa I, Giasson BI, Sasaki R, Zhang B, Joyce S, Uryu K, Trojanowski JQ, Lee VM: Mouse model of multiple system atrophy alpha-synuclein expression in oligodendrocytes causes glial and neuronal degeneration. Neuron 2005, 45:847-859.

102. Lee HJ, Suk JE, Bae EJ, Lee SJ: Clearance and deposition of extracellular alpha-synuclein aggregates in microglia. Biochem Biophys Res Commun 2008, 372:423-428.

103. Lee HJ, Suk JE, Patrick C, Bae EJ, Cho JH, Rho S, Hwang D, Masliah E, Lee SJ: Direct transfer of alpha-synuclein from neuron to astroglia causes inflammatory responses in synucleinopathies. J Biol Chem 2010, 285:9262-9272.

104. Toledo JB, Cairns NJ, Da X, Chen K, Carter D, Fleisher A, Householder E, Ayutyanont N, Roontiva A, Bauer RJ, Eisen P, Shaw LM, Davatzikos C, Weiner MW, Reiman EM, Morris JC, Trojanowski JQ: Clinical and multimodal biomarker correlates of ADNI neuropathological findings. Acta Neuropathol Commun 2013, 1:65.

105. Mikolaenko I, Pletnikova O, Kawas CH, O'Brien R, Resnick SM, Crain B, Troncoso JC: Alpha-synuclein lesions in normal aging, Parkinson disease, and Alzheimer disease: evidence from the Baltimore Longitudinal Study of Aging (BLSA). J Neuropathol Exp Neurol 2005, 64:156-162.

106. Hamilton RL: Lewy bodies in Alzheimer's disease: a neuropathological review of 145 cases using alpha-synuclein immunohistochemistry. Brain Pathol 2000, 10:378-384. 
107. Iseki E: Dementia with Lewy bodies: reclassification of pathological subtypes and boundary with Parkinson's disease or Alzheimer's disease. Neuropathology 2004, 24:72-78.

108. Marui W, Iseki E, Ueda K, Kosaka K: Occurrence of human alpha-synuclein immunoreactive neurons with neurofibrillary tangle formation in the limbic areas of patients with Alzheimer's disease. J Neurol Sci 2000, 174:81-84.

109. Compta Y, Parkkinen L, O'Sullivan SS, Vandrovcova J, Holton JL, Collins C, Lashley T, Kallis C, Williams DR, de Silva R, Lees AJ, Revesz T: Lewy- and Alzheimer-type pathologies in Parkinson's disease dementia: which is more important? Brain 2011, 134:1493-1505.

110. Kovari E, Gold G, Herrmann FR, Canuto A, Hof PR, Bouras C, Giannakopoulos $P$ : Lewy body densities in the entorhinal and anterior cingulate cortex predict cognitive deficits in Parkinson's disease. Acta Neuropathol 2003, 106:83-88.

111. Jellinger KA, Seppi K, Wenning GK, Poewe W: Impact of coexistent Alzheimer pathology on the natural history of Parkinson's disease. I Neural Transm 2002, 109:329-339.

112. Irwin DJ, White MT, Toledo JB, Xie SX, Robinson JL, Van Deerlin V, Lee VM, Leverenz JB, Montine TJ, Duda JE, Hurtig HI, Trojanowski JQ: Neuropathologic substrates of Parkinson disease dementia. Ann Neurol 2012, 72:587-598.

113. Clinton LK, Blurton-Jones M, Myczek K, Trojanowski JQ, LaFerla FM: Synergistic interactions between Abeta, tau, and alpha-synuclein: acceleration of neuropathology and cognitive decline. J Neurosci 2010 30:7281-7289

114. Giasson BI, Duda JE, Quinn SM, Zhang B, Trojanowski JQ, Lee VM: Neuronal alpha-synucleinopathy with severe movement disorder in mice expressing A53T human alpha-synuclein. Neuron 2002, 34:521-533.

115. Rolinski M, Fox C, Maidment I, McShane R: Cholinesterase inhibitors for dementia with Lewy bodies. Parkinson's disease dementia and cognitive impairment in Parkinson's disease. Cochrane Database Syst Rev 2012, 3:CD006504.

116. Ballard CG, Chalmers KA, Todd C, McKeith IG, O'Brien JT, Wilcock G, Love S, Perry EK: Cholinesterase inhibitors reduce cortical Abeta in dementia with Lewy bodies. Neurology 2007, 68:1726-1729.

117. Vekrellis K, Stefanis L: Targeting intracellular and extracellular alphasynuclein as a therapeutic strategy in Parkinson's disease and other synucleinopathies. Expert Opin Ther Targets 2012, 16:421-432.

118. Lee HJ, Bae EJ, Lee SJ: Extracellular alpha-synuclein - a novel and crucial factor in Lewy body diseases. Nat Rev Neurol 2014, 10:92-98.

119. Marchiani A, Mammi S, Siligardi G, Hussain R, Tessari I, Bubacco L, Delogu G, Fabbri D, Dettori MA, Sanna D, Dedola S, Serra PA, Ruzza P: Small molecules interacting with alpha-synuclein: antiaggregating and cytoprotective properties. Amino Acids 2013, 45:327-338.

120. Moloney TC, Hyland R, O'Toole D, Paucard A, Kirik D, O'Doherty A, Gorman AM, Dowd E: Heat shock protein 70 reduces alpha-synuclein-induced predegenerative neuronal dystrophy in the alpha-synuclein viral gene transfer rat model of Parkinson's disease. CNS Neurosci Ther 2014, 20:50-58.

121. Putcha P, Danzer KM, Kranich LR, Scott A, Silinski M, Mabbett S, Hicks CD, Veal JM, Steed PM, Hyman BT, McLean PJ: Brain-permeable small-molecule inhibitors of Hsp90 prevent alpha-synuclein oligomer formation and rescue alpha-synuclein-induced toxicity. J Pharmacol Exp Ther 2010, 332:849-857.

122. Toth G, Gardai SJ, Zago W, Bertoncini CW, Cremades N, Roy SL, Tambe MA, Rochet JC, Galvagnion C, Skibinski G, Finkbeiner S, Bova M, Regnstrom K, Chiou SS, Johnston J, Callaway K, Anderson JP, Jobling MF, Buell AK, Yednock TA, Knowles TP, Vendruscolo M, Christodoulou J, Dobson CM, Schenk D, McConlogue L: Targeting the intrinsically disordered structural ensemble of alpha-synuclein by small molecules as a potential therapeutic strategy for Parkinson's disease. PLoS One 2014, 9:e87133.

123. Jones DR, Moussaud S, McLean P: Targeting heat shock proteins to modulate alpha-synuclein toxicity. Ther Adv Neurol Disord 2014, 7:33-51.

124. Sinha G: Roche bets on alpha-synuclein for Parkinson's. Nat Biotechnol 2014, 32:212.

125. Valera E, Masliah E: Immunotherapy for neurodegenerative diseases: focus on alpha-synucleinopathies. Pharmacol Ther 2013, 138:311-322.

126. Mandler M, Valera E, Rockenstein E, Weninger H, Patrick C, Adame A, Santic R, Meindl S, Vigl B, Smrzka O, Schneeberger A, Mattner F, Masliah E: Next-generation active immunization approach for synucleinopathies: implications for Parkinson's disease clinical trials. Acta Neuropathol 2014, 127:861-879.

127. Lindstrom V, Ihse E, Fagerqvist T, Bergstrom J, Nordstrom E, Moller C, Lannfelt L, Ingelsson M: Immunotherapy targeting alpha-synuclein, with relevance for future treatment of Parkinson's disease and other Lewy body disorders. Immunotherapy 2014, 6:141-153.

128. Ruzza P, Siligardi G, Hussain R, Marchiani A, Islami M, Bubacco L, Delogu G, Fabbri D, Dettori MA, Sechi M, Pala N, Spissu Y, Migheli R, Serra PA, Sechi G: Ceftriaxone blocks the polymerization of alpha-synuclein and exerts neuroprotective effects in vitro. ACS Chem Neurosci 2014, 5:30-38.

129. Low PA, Robertson D, Gilman S, Kaufmann H, Singer W, Biaggioni I, Freeman R, Perlman S, Hauser RA, Cheshire W, Lessig S, Vernino S, Mandrekar J, Dupont WD, Chelimsky T, Galpern WR: Efficacy and safety of rifampicin for multiple system atrophy: a randomised, double-blind, placebo-controlled trial. Lancet Neurol 2014, 13:268-275.

doi:10.1186/s13195-014-0073-2

Cite this article as: Kim et al:: Alpha-synuclein biology in Lewy body diseases. Alzheimer's Research \& Therapy 2014 6:73. 